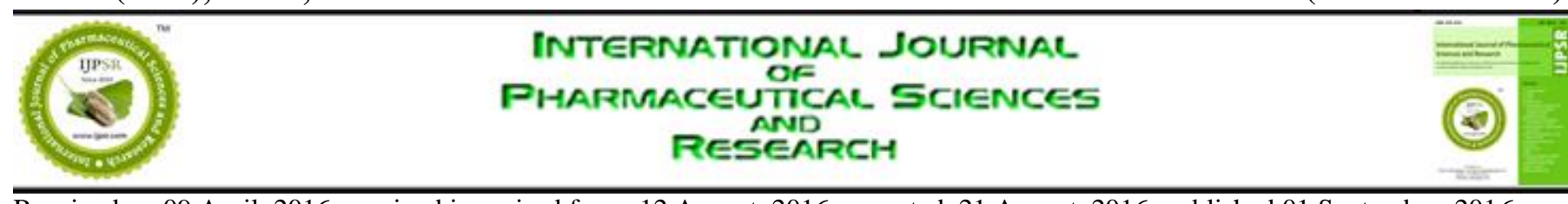

Received on 09 April, 2016; received in revised form, 12 August, 2016; accepted, 21 August, 2016; published 01 September, 2016

\title{
DEVELOPMENT AND VALIDATION OF RP-HPLC METHOD FOR SIMULTANEOUS ESTIMATION OF CEFPODOXIME PROXETIL AND LEVOFLOXACIN HEMIHYDRATE IN COMBINED DOSAGE FORM
}

Shuchi M. Desai ${ }^{*}$, Hitesh Dalwadi, Dhansukh Viradiya

ROFEL Shri G.M Bilakhia college of Pharmacy, Vapi, Gujarat, India

Keywords:

RP-HPLC, Simultaneous estimation, System suitability, Cefpodoxime Proxetil, Levofloxacin hemihydrate

Correspondence to Author:

Shuchi Mehul Desai

Assistant Professor,

Department of Quality Assurance,

ROFEL Shri G.M Bilakhia college of

Pharmacy, Vapi, Gujarat - 396191, India.

Email: shuchi.desai89@gmail.com
ABSTRACT: A simple, accurate, precise, rapid and economical RPHPLC method was developed for the estimation of Cefpodoxime Proxetil (CPD) and Levofloxacin hemihydrate (LVX) in tablet dosage

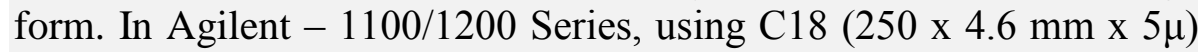
column and with mobile phase composition of Phosphate buffer: Acetonitrile $(\mathrm{pH} 6.0)(50: 50 \mathrm{v} / \mathrm{v})$ at a flow rate of $1 \mathrm{ml} / \mathrm{min}$ was used. Detection was carried out at $240 \mathrm{~nm}$. Retention time of CPD and LVX was found to be $5.64 \& 5.97 \mathrm{~min}$ and $2.79 \mathrm{~min}$, respectively. The method has been validated for linearity, accuracy and precision, LOD, LOQ and System suitability according to ICH Q2R1 Guideline.
INTRODUCTION: Cefpodoxime is an oral third generation cephalosporin antibiotic. It is active against most Gram positive and Gram negative bacteria. It is commonly used to treat acute otitis media, pharyngitis, and sinusitis. Chemically it is 1-(isopropoxycarbonyloxy) ethyl (6R, 7R)-7-[2-(2amino-4 thiazolyl) - (Z) - 2 - (methoxyimino) acetamido] - 3 - methoxymethyl - 3 - cephem - 4carboxylate. Levofloxacin is an antibiotic, anti bacterial agent and anti infective agent. Chemically it is (2S)-7-fluoro-2-methyl-6-(4-methylpiperazin1-yl)-10-oxo-4-oxa-1-azatricyclo [7.3.1.0 $\{5,13\}$ ]trideca-5(13),6,8,11-tetraene-11-carboxylic acid. The tablet Glevopod contains the combination of Cefpodoxime Proxetil (200mg) and Levofloxacin Hemihydrate $(250 \mathrm{mg})$. Glenmark pharmaceuticals Ltd. had manufactured the tablet.

\begin{tabular}{|l|c|}
\hline QUICK RESPONSE CODE & $\begin{array}{c}\text { DOI: } \\
\text { 10.13040/IJPSR.0975-8232.7(9).3742-48 }\end{array}$ \\
\hline \multicolumn{2}{|c|}{$\begin{array}{c}\text { Article can be accessed online on: } \\
\text { www.ijpsr.com }\end{array}$} \\
\hline DOI link: http://dx.doi.org/10.13040/IJPSR.0975-8232.7 (9).3742-48 \\
\hline
\end{tabular}

A literature survey revealed that only a few methods based on HPLC ${ }^{3,4,5}$, Spectrometry and HPTLC ${ }^{6,7,8,9}$ were reported for the determination of Cefpodoxime and Levofloxacin individually but no single method is reported for the simultaneous estimation Cefpodoxime and Levofloxacin in pharmaceutical dosage form. Hence in the present study a physical mixture of Cefpodoxime and Levofloxacin was being taken for simultaneous estimation by HPLC method. This present investigation describes a rapid, accurate and precise UV method of Cefpodoxime and Levofloxacin in combination using Phosphate buffer:Acetonitrile $(\mathrm{pH} 6.0)(50: 50 \mathrm{v} / \mathrm{v})$ as a mobile phase.

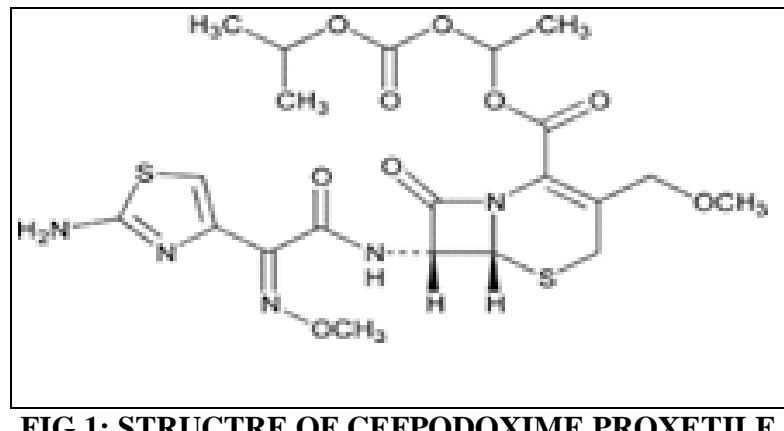




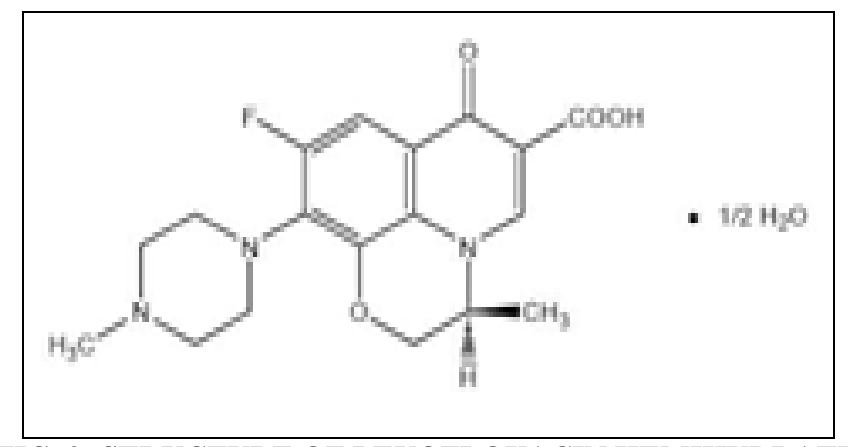

FIG. 2: STRUCTURE OF LEVOFLOXACIN HEMIHYDRATE

MATERIALS AND METHODS:

Apparatus and Instruments:

- Model: Agilent - 1100/1200 Series.

- Column: C18 (250 x $4.6 \mathrm{~mm}, 5 \mu \mathrm{m})$

- Injector: An auto injector

- Detector: PDA Detector

- Software: Chem - 32 Software

- Analytical balance: Electronic analytical balance (Mettler Toledo)

- Volumetric flasks and pipettes (Borosil)

\section{Reagents and Chemicals:}

- Cefpodoxime Proxetil (Gift sample, Sunrise Remedies, Ahemdabad)

- Levofloxacin Hemihydrate (Gift sample, Sunrise Remedies, Ahemdabad)

- Distilled water (HPLC grade-SD Fine chemical Pvt. Ltd)

- Acetonitrile (HPLC grade-SD Fine chemical pvt. Ltd)

- Methanol (HPLC grade-SD Fine chemical pvt. Ltd)

- Potassium dihydrogen ortho phosphate (SD Fine chemical pvt. Ltd)

- Ortho Phosphoric acid (SD Fine chemical pvt. Ltd)

- Potassium hydroxide (SD Fine chemical pvt. Ltd)

Preparation of Standard Solution: All chemicals and reagents used were of AR/HPLC grade. Pure standards of CPD and LVX were obtained from Sunrise remedies, Ahmedabad.

Preparation of buffer: A 6.8 gm of potassium dihydrogen orthophosphate was dissolved in 900 $\mathrm{ml}$ of Distilled water. Then the $\mathrm{pH}$ was adjusted to 6.0 with $\mathrm{KOH}$. Then the volume was made up to
$1000 \mathrm{ml}$ and was filtered through $0.45 \mu \mathrm{m}$ membrane filter and degassed.

Preparation of mobile phase: A degassed mixture of Phosphate buffer and Acetonitrile in the ratio of 50:50 (v/v) was prepared and the mixture was filtered through $0.45 \mu$ membrane filters and it was degassed.

Preparation of standard stock solution Cefpodoxime Proxetil (CPD) $(1000 \mu \mathrm{g} / \mathrm{ml})$ : Accurately weighed CPD $100 \mathrm{mg}$ was transferred into $100 \mathrm{ml}$ volumetric flask and dissolved in acetonitrile and diluted up to the mark with acetonitrile to give a stock solution having strength $1000 \mu \mathrm{g} / \mathrm{ml}$.

Preparation of standard stock solution Levofloxacin Hemihydrate (LVX) $(1250 \mu \mathrm{g} / \mathrm{ml})$ :

Accurately weighed LVX $125 \mathrm{mg}$ was transferred into $100 \mathrm{ml}$ volumetric flask and dissolved in acetonitrile and diluted up to the mark with acetonitrile to give a stock solution having strength $1250 \mu \mathrm{g} / \mathrm{ml}$.

Preparation of standard solution of binary mixtures of CPD and LVX: Accurately weighed 4 $\mathrm{mg}$ of CPD and $5 \mathrm{mg}$ of LVX were transferred to $50 \mathrm{ml}$ volumetric flask and diluted up to mark with diluent to give concentration of $80 \mu \mathrm{g} / \mathrm{ml}$ of CPD and $100 \mu \mathrm{g} / \mathrm{ml}$ of LVX.

Calibration Curve of Cefpodoxime Proxetil and Levofloxacin Hemihydrate: Calibration curves were prepared by taking appropriate aliquots 0.2 , $0.4,0.6,0.8,1$ and $1.2 \mathrm{ml}$ of stock solution of CPD and $0.2,0.4,0.6,0.8,1$ and $1.2 \mathrm{ml}$ stock solution of LVX in $10 \mathrm{ml}$ vol. flask and dilute up to the mark with acetonitrile to give $20-120 \mu \mathrm{g} / \mathrm{ml}$ of CPD and $25-150 \mu \mathrm{g} / \mathrm{ml}$ of LVX.

The standard solution was run for 10 minutes using mobile phase at a flow rate of $1 \mathrm{ml} / \mathrm{min}$. The graph of peak area vs concentration was plotted, regression equation and correlation co- efficient for both drugs were obtained.

Chromatographic separation: Standard solutions of $20-120 \mu \mathrm{g} / \mathrm{ml}$ of CPD and $25-150 \mu \mathrm{g} / \mathrm{ml} \mathrm{LVX}$ were injected in column with $20 \mu \mathrm{l}$ micro-syringe. The chromatogram was run for appropriate minutes with mobile phase Phosphate buffer: Acetonitrile 
$(50: 50 \mathrm{v} / \mathrm{v})$. The detection was carried out at wavelength $240 \mathrm{~nm}$. The chromatogram was stopped after separation achieved completely. Data related to peak like area, height, retention time, resolution etc.

\section{Validation of RP-HPLC Method:}

(A) Linearity: Aliquots of standard solutions of CPD and LVX in range 20-120 $\mu \mathrm{g} / \mathrm{ml}$ and 25-150 $\mu \mathrm{g} / \mathrm{ml}$ respectively, was prepared from working standard solution and injected to system with stated chromatographic conditions and analyzed. The graph of peak area obtained versus respective concentration was plotted. The mean area with its standard deviation and \% relative standard deviation of peak were calculated.

\section{(B) Precision:}

I. Repeatability: Three different standard solutions of CPD (40, 80 and $120 \mu \mathrm{g} / \mathrm{ml})$ were prepared from working standard solution and injected three times to system with stated chromatographic conditions and analyzed. Three different standard solutions of LVX $(50,100$ and $150 \mu \mathrm{g} / \mathrm{ml})$ were prepared from working standard solution and injected three times to system with stated chromatographic conditions and analyzed.

II. Intraday precision: Standard solutions CPD $(40,80$, and $120 \mu \mathrm{g} / \mathrm{ml})$ and $\operatorname{LVX}(50,100$, and $150 \mu \mathrm{g} / \mathrm{ml}$ ) were prepared from working standard solution and injected in to system with stated chromatographic conditions and analyzed, three times in a day.

\section{Interday precision:}

Standard solutions CPD (40, 80, and $120 \mu \mathrm{g} / \mathrm{ml})$ and $\operatorname{LVX}(50,100$, and $150 \mu \mathrm{g} / \mathrm{ml})$ were prepared from working standard solution and injected in to system with stated chromatographic conditions and analyzed, three days.

\section{(C) Accuracy:}

\section{Procedure:}

\section{Preparation of Sample Solution:}

Tablet Solution X: CPD $(1000 \mu \mathrm{g} / \mathrm{ml})+$ LVX $(1250 \mu \mathrm{g} / \mathrm{ml}$ ) (final dilution contain CPD 1000 $\mu \mathrm{g} / \mathrm{ml}$ and LVX $1250 \mu \mathrm{g} / \mathrm{ml})$

Standard solution Y: CPD $(1000 \mu \mathrm{g} / \mathrm{ml}) \&$

Standard solution Z: LVX $(1250 \mu \mathrm{g} / \mathrm{ml})$
The amount of CPD and LVX was calculated at each level $(80 \%, 100 \% \& 120 \%)$ and \% recoveries were computed.

(D) Robustness: It should show the reliability of an analysis with respect to deliberate variations in method parameters.

In case of liquid chromatography, examples of typical variations are

- Influence of variations of $\mathrm{pH}( \pm 0.2)$ in a mobile phase

- Influence of variations in mobile phase $( \pm 2)$ composition,

- Flow rate. $( \pm 0.2)$

(E) Specificity: Specificity is a procedure to detect quantitatively the analyte in the presence of components that may be expected to be present in the sample matrix. While selectivity is the procedure to detect qualitatively the analyte in presence of components that may expected to be present in the sample matrix. Specificity of developed method was established by spiking of CPD and LVX in hypothetical placebo (i.e. might be expected to be present) and expressing that analytes peak were not interfered from excipients.

(F) LOD and LOQ: The LOD (Limit of Detection) was estimated from the set of 6 calibration curves used to determine method linearity. The LOD may be calculated as

$$
\text { LOD = } 3.3 \times(\text { S.D. } / \text { Slope })
$$

Where,

$\mathrm{SD}=$ Standard deviation of the response

Slope $=$ Mean slope of calibration curves

The LOQ (Limit of Quantitation) was estimated from the set of 6 calibration curves used to determine method linearity. The LOQ may be calculated as

Where,

$$
\text { LOQ = } 10 \times(\text { S.D./Slope })
$$

$\mathrm{SD}=$ Standard deviation of the response

Slope $=$ Mean slope of calibration curves

Analysis of Tablet Formulation: This method was applied to determine CPD and LVX in tablet dosage form. Total 20 tablets were accurately weighted and triturated with glass mortar and 
pestle. The powder equivalent to $8 \mathrm{mg}$ of CPD and $10 \mathrm{mg}$ of LVX was taken in $100 \mathrm{ml}$ volumetric flask; acetonitrile was added and the flask was kept in an ultrasonic bath for $10 \mathrm{~min}$. The volume was made up to mark and the solution was filtered through 0.45 micro membrane filter. The diluted solution was analyzed under optimized chromatographic conditions. The areas of resulting peak were measured at $240 \mathrm{~nm}$.

\section{RESULT AND DISCUSSION:}

Selection of wavelength: Both Cefpodoxime Proxetil and Levofloxacin Hemihydrate show reasonably good response at $230 \mathrm{~nm}$. Mention in Fig.

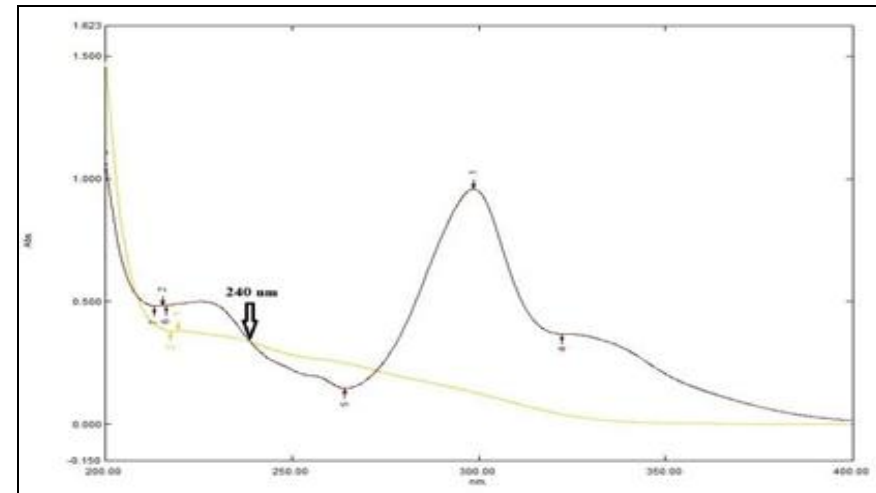

FIG.3: OVERLAY UV SPECTRUM OF CEFPODOXIME PROXETIL AND LEVOFLOXACIN HEMIHYDRATE SHOWING SELECTION OF WAVELENGTH DETECTION

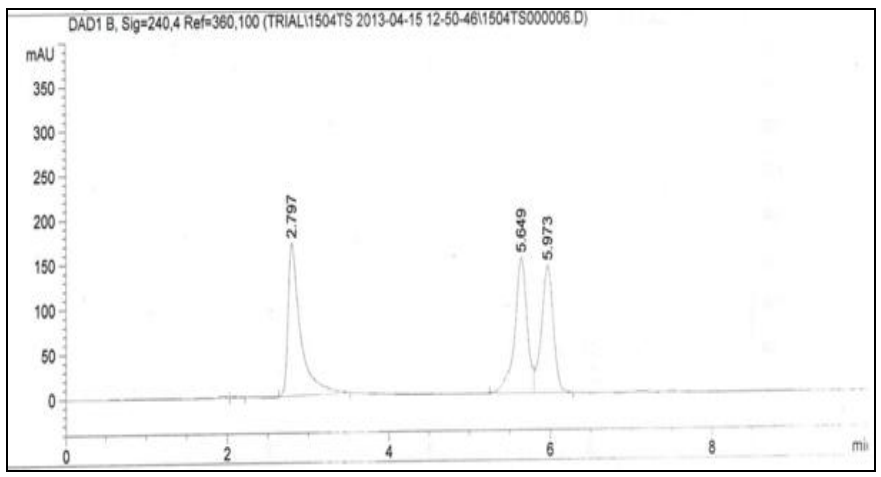

FIG. 4: CHROMATOGRAM OF CEFPODOXIME PROXETIL AND LEVOFLOXACIN

Hemihydrate in Phosphate buffer:Acetonitrile $(50: 50 \mathrm{v} / \mathrm{v})($ Flow rate $1 \mathrm{ml} / \mathrm{min})$ :

TABLE 1: OBSERVED VALUES FOR SYSTEM SUITABILITY TEST

\begin{tabular}{ccc}
\hline Parameters & \multicolumn{2}{c}{ Data obtained } \\
\hline & CPD & LVX \\
\hline Theoretical plates per column & 8674 & 2422 \\
Symmetry factor/Tailing factor & 1.16 & 0.42 \\
Resolution & \multicolumn{2}{c}{12.02} \\
\hline
\end{tabular}

\section{Method Validation:}

\section{(A)Linearity and Range:}

The linearity range for CPD and LVX was found to be in the range of $20-120 \mu \mathrm{g} / \mathrm{ml}$ and $25-150 \mu \mathrm{g} / \mathrm{ml}$ respectively. Correlation co-efficient for calibration curve of CPD and LVX was found to be 0.999 and 0.998 respectively.

The regression line equation for CPD and LVX are as following:

$$
\begin{aligned}
& \text { For CPD: } y=(29.98) \times(x)+34.92 \\
& \text { For LVX: } y=(15.87) \times(x)-119.7
\end{aligned}
$$

Where,

$\mathrm{y}=$ Corresponding peak area

$\mathrm{x}=$ Concentration of drug in $\mu \mathrm{g} / \mathrm{ml}$

TABLE: 2 LINEARITY DATA FOR CPD

\begin{tabular}{cccc}
\hline Sr.no & $\begin{array}{c}\text { Concentration } \\
(\boldsymbol{\mu} \mathbf{g} / \mathbf{m l})\end{array}$ & $\begin{array}{c}\text { Area } \\
\text { Mean } \pm \text { S.D. }(\mathbf{n}=\mathbf{3})\end{array}$ & \%RSD \\
\hline 1. & 20 & $611.36 \pm 5.1903$ & 0.8489 \\
2. & 40 & $1239.09 \pm 3.8617$ & 0.3116 \\
3. & 60 & $1871.69 \pm 3.5996$ & 0.1923 \\
4. & 80 & $2420.63 \pm 3.9861$ & 0.1646 \\
5. & 100 & $3044.29 \pm 4.6287$ & 0.1521 \\
6. & 120 & $3616.42 \pm 4.2351$ & 0.1171 \\
\hline
\end{tabular}

TABLE: 3 LINEARITY DATA FOR LVX

\begin{tabular}{cccc}
\hline Sr.no & $\begin{array}{c}\text { Concentration } \\
(\boldsymbol{\mu} \mathbf{g} / \mathbf{m l})\end{array}$ & $\begin{array}{c}\text { Area } \\
\text { Mean } \pm \text { S.D. }(\mathbf{n}=3)\end{array}$ & \%RSD \\
\hline 1. & 25 & $288.8 \pm 4.2571$ & 1.4738 \\
2. & 50 & $690.91 \pm 3.8136$ & 0.5519 \\
3. & 75 & $1045.53 \pm 1.7303$ & 0.1654 \\
4. & 100 & $1461.75 \pm 3.4045$ & 0.2329 \\
5. & 125 & $1825.44 \pm 3.0759$ & 0.1685 \\
6. & 150 & $2302.82 \pm 3.6074$ & 0.1566 \\
\hline
\end{tabular}

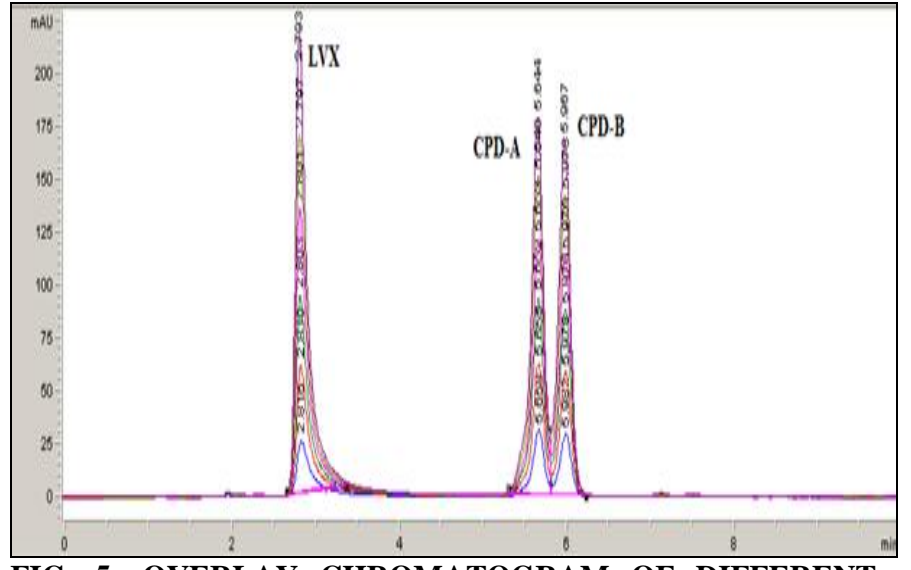

FIG. 5: OVERLAY CHROMATOGRAM OF DIFFERENT CONCENTRATIONS OF BINARY MIXTURE OF CPD AND LVX 


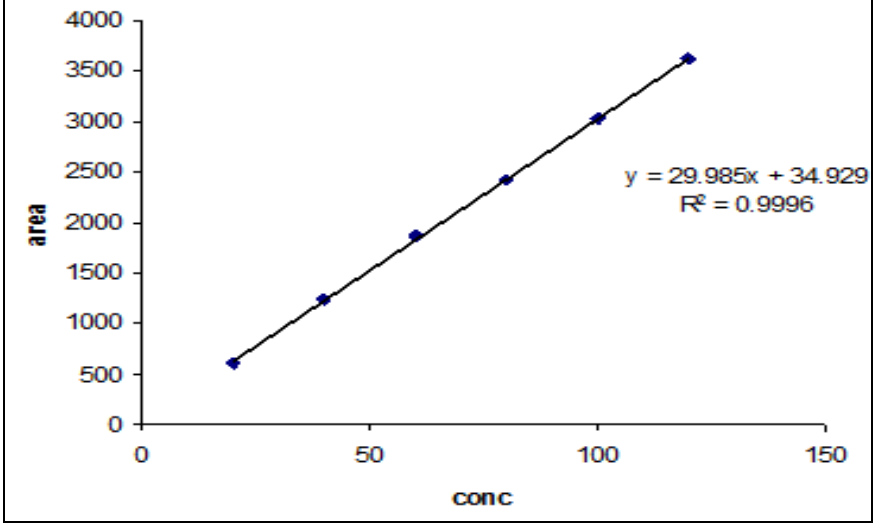

CALIBRATION CURVE FOR CPD

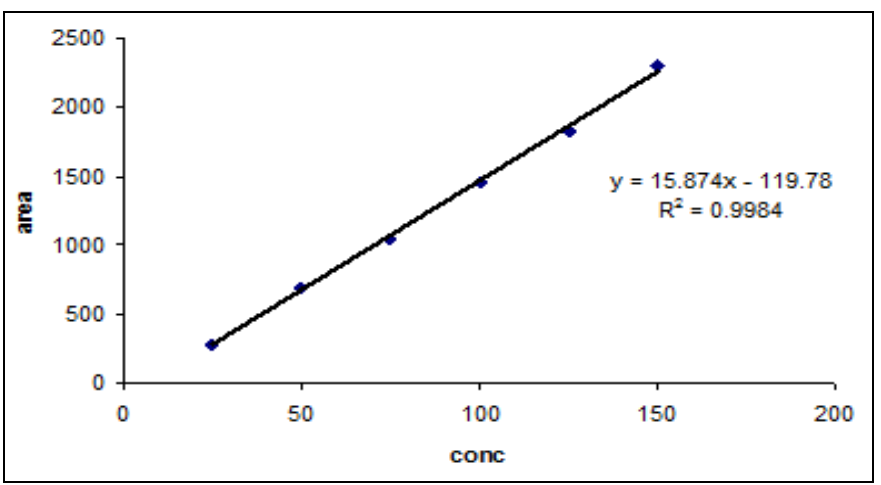

(B) Precision:

I. Repeatability: The data for repeatability of peak area measurement for CPD and LVX, based on three measurements of three different solution of CPD and LVX, are depicted in Table 4 and $\mathbf{5}$ respectively.

\begin{tabular}{cccc}
\multicolumn{4}{c}{ TABLE: 4 REPEATABILITY DATA FOR CPD } \\
\hline Sr. no. & $\begin{array}{c}\text { Concentration } \\
(\boldsymbol{\mu g} / \mathbf{m l})\end{array}$ & $\begin{array}{c}\text { Area Mean } \\
(\text { Mean } \pm \text { S.D })\end{array}$ & $\begin{array}{c}\text { \% RSD } \\
(\mathbf{n}=\mathbf{6})\end{array}$ \\
\hline 1 & 40 & $1240.68 \pm 11.54$ & 0.9304 \\
2 & 80 & $2425.97 \pm 24.52$ & 1.0111 \\
3 & 120 & $3613.65 \pm 11.78$ & 0.3261 \\
\hline
\end{tabular}

TABLE: 5 REPEATABILITY DATA FOR LVX

\begin{tabular}{cccc}
$\begin{array}{c}\text { Sr. } \\
\text { no. }\end{array}$ & $\begin{array}{c}\text { Concentration } \\
(\boldsymbol{\mu g} / \mathbf{m l})\end{array}$ & $\begin{array}{c}\text { Area Mean } \\
(\text { Mean } \pm \text { S.D })\end{array}$ & $\begin{array}{c}\text { \% RSD } \\
(\mathbf{n = 6})\end{array}$ \\
\hline 1 & 50 & $693.24 \pm 7.65$ & 1.1037 \\
2 & 100 & $1455.68 \pm 18.22$ & 1.2521 \\
3 & 150 & $2300.09 \pm 13.11$ & 0.5696 \\
\hline
\end{tabular}

\section{Intraday precision:}

The data for intraday precision for CPD and LVX is shown in Table 5.

CALIBRATION CURVE FOR LVX

TABLE 5: INTRADAY PRECISION DATA FOR ESTIMATION OF CPD AND LVX

\begin{tabular}{|c|c|c|c|c|c|}
\hline \multicolumn{3}{|c|}{ CPD } & \multicolumn{3}{|c|}{ LVX } \\
\hline $\begin{array}{l}\text { Conc. } \\
(\mu \mathrm{g} / \mathrm{ml})\end{array}$ & $\begin{array}{c}\text { Area } \\
\text { Mean } \pm \text { S.D. }(n=3)\end{array}$ & $\%$ RSD & $\begin{array}{c}\text { Conc. } \\
(\mu \mathrm{g} / \mathrm{ml})\end{array}$ & $\begin{array}{c}\text { Area } \\
\text { Mean } \pm \text { S.D. }(n=3)\end{array}$ & $\%$ RSD \\
\hline 80 & $2420.37 \pm 11.2545$ & 0.4649 & 100 & $1461.52 \pm 12.6153$ & 0.8631 \\
\hline 120 & $3615.93 \pm 12.505$ & 0.3458 & 150 & $2302.63 \pm 15.9831$ & 0.6941 \\
\hline
\end{tabular}

III. Interday Precision: The data for Interday precision for CPD and LVX is shown in Table 6.

TABLE 6: INTERDAY PRECISION DATA FOR ESTIMATION OF CPD AND LVX

\begin{tabular}{cccccc}
\hline & CPD & & \multicolumn{2}{c}{ LVX } \\
\hline $\begin{array}{c}\text { Conc. } \\
(\boldsymbol{\mu g} / \mathbf{m l})\end{array}$ & $\begin{array}{c}\text { Area } \\
\text { Mean } \pm \text { S.D. }(\mathbf{n}=\mathbf{3})\end{array}$ & $\boldsymbol{\%}$ RSD & $\begin{array}{c}\text { Conc. } \\
(\boldsymbol{\mu g} / \mathbf{m l})\end{array}$ & $\begin{array}{c}\text { Area } \\
\text { Mean } \pm \text { S.D. }(\mathbf{n}=\mathbf{3})\end{array}$ & \% RSD \\
\hline 40 & $1236.47 \pm 15.9559$ & 1.2904 & 50 & $691.67 \pm 10.1900$ & 1.4732 \\
80 & $2419.20 \pm 16.6104$ & 0.6866 & 100 & $1461.64 \pm 13.8049$ & 0.9444 \\
120 & $3616.37 \pm 15.1707$ & 0.4195 & 150 & $2301.26 \pm 17.3607$ & 0.7544 \\
\hline
\end{tabular}

(C) Accuracy: The data for Accuracy for CPD and LVX is shown in Table $\mathbf{7}$ and $\mathbf{8 .}$

TABLE 7: RECOVERY DATA FOR CPD

\begin{tabular}{ccccccc}
$\begin{array}{c}\text { Conc. } \\
\text { level }\end{array}$ & $\begin{array}{c}\text { Amount } \\
\text { Of Sample } \\
\text { Drug Taken } \\
(\boldsymbol{\mu g} / \mathbf{m l})\end{array}$ & $\begin{array}{c}\text { Amount } \\
\text { Of Standard } \\
\text { Drug Added }\end{array}$ & $\begin{array}{c}\text { Area } \\
(\boldsymbol{\mu g} / \mathbf{m l})\end{array}$ & $\begin{array}{c}\text { Amount } \\
\text { recovered } \\
(\boldsymbol{\mu g} / \mathbf{m l})\end{array}$ & $\begin{array}{c}\% \\
\text { Recovery }\end{array}$ & $\begin{array}{c}\text { \%Mean } \\
\text { Recovery } \\
\pm \text { SD }\end{array}$ \\
\hline 80 & 80 & 64 & 465973.9 & 64.59 & 100.93 & $100.29 \pm 0.7497$ \\
& 80 & 64 & 466810.3 & 64.30 & 100.48 & 0.7475 \\
100 & 80 & 64 & 464961.5 & 63.66 & 99.46 & $99.82 \pm 0.3361$ \\
& 80 & 80 & 513190.1 & 80.15 & 100.19 & 0.3367 \\
\hline
\end{tabular}




\begin{tabular}{lllllcll}
\hline \multirow{2}{*}{120} & 80 & 80 & 511964.1 & 79.78 & 99.73 & & \\
& 80 & 96 & 561471.4 & 96.42 & 100.44 & $100.09 \pm 0.3413$ & 0.3409 \\
& 80 & 96 & 558792.3 & 95.77 & 99.76 & & \\
& 80 & 96 & 557263.9 & 96.08 & 100.08 & & \\
\hline
\end{tabular}

TABLE 8: RECOVERY DATA FOR LVX

\begin{tabular}{cccccccc}
\hline $\begin{array}{c}\text { Conc. } \\
\text { level }\end{array}$ & $\begin{array}{c}\text { Amount } \\
\text { Of Sample } \\
\text { Drug Taken } \\
(\boldsymbol{\mu g} / \mathbf{m l})\end{array}$ & $\begin{array}{c}\text { Amount } \\
\text { of Standard } \\
\text { Drug Added } \\
(\boldsymbol{\mu} \mathbf{g} / \mathbf{m l})\end{array}$ & Area & $\begin{array}{c}\text { Amount } \\
\text { recovered } \\
(\boldsymbol{\mu g} / \mathbf{m l})\end{array}$ & $\begin{array}{c}\text { \% } \\
\text { Recovery }\end{array}$ & $\begin{array}{c}\text { \%Mean } \\
\text { Recovery } \\
\mathbf{\pm} \text { SD }\end{array}$ & $\%$ RSD \\
\hline 80 & 100 & 80 & 465973.9 & 79.45 & 99.09 & $99.89 \pm 1.5500$ & 1.5516 \\
& 100 & 80 & 466810.3 & 81.32 & 99.54 & & \\
100 & 100 & 80 & 464961.5 & 78.97 & 98.55 & & 1.4881 \\
& 100 & 100 & 513190.1 & 99.59 & 99.49 & $99.91 \pm 1.4868$ & \\
& 100 & 100 & 513290.1 & 101.53 & 99.53 & & 0.8428 \\
& 100 & 100 & 511964.1 & 98.61 & 98.97 & & \\
\hline
\end{tabular}

D) Robustness: The data for Robustness for CPD and LVX is shown in Table 9 and $\mathbf{1 0 .}$

TABLE 9: ROBUSTNESS DATA FOR CPD

\begin{tabular}{ccccccc}
\hline Sr. no. & Flow rate & Flow rate & M.P + 2 & M.P - 2 & pH + 0.2 & pH - 0.2 \\
& $\mathbf{+ 0 . 2}$ & $\mathbf{- 0 . 2}$ & & & & \\
\hline 1 & 2330.11 & 2501.71 & 2408.46 & 2443.82 & 2412.43 & 2453.11 \\
2 & 2313.19 & 2584.99 & 2396.31 & 2397.09 & 2378.38 & 2389.61 \\
3 & 2390.06 & 2585.11 & 2448.08 & 2464.72 & 2436.17 & 2426.86 \\
\%RSD & 1.7228 & 1.8815 & 1.1197 & 1.4219 & 1.2058 & 1.3167 \\
\hline
\end{tabular}

TABLE 10: ROBUSTNESS DATA FOR LVX

\begin{tabular}{ccccccc}
\hline Sr. no. & Flow rate & Flow rate & M.P + 2 & M.P - 2 & pH + 0.2 & pH - 0.2 \\
& $\mathbf{+ 0 . 2}$ & $\mathbf{- 0 . 2}$ & & & & \\
\hline $\mathbf{1}$ & 1298.06 & 1550.22 & 1469.11 & 1414.05 & 1411.55 & 1429.41 \\
$\mathbf{2}$ & 1286.52 & 1538.79 & 1483.43 & 1383.86 & 1396.35 & 1391.46 \\
$\mathbf{3}$ & 1315.91 & 1507.54 & 1451.94 & 1432.14 & 1444.37 & 1413.16 \\
$\mathbf{\%}$ RSD & 1.1388 & 1.4419 & 1.0738 & 1.7298 & 1.7315 & 1.3491 \\
\hline
\end{tabular}

(E) Limit of Detection (LOD) \& Limit of Quantification (LOQ):

TABLE 11: LOD AND LOQ DATA FOR CPD AND LVX

\begin{tabular}{ccc}
\hline Parameters & CPD & LVX \\
\hline LOD & 1.2305 & 1.9874 \\
LOQ & 3.7289 & 6.0226 \\
\hline
\end{tabular}

(F) Applicability of the method:

Analysis of marketed formulation: Applicability commercially available tablet formulation GLEVOof the proposed method was tested by analyzing the POD. The results are shown in Table.

TABLE 12: ANALYSIS OF MARKETED FORMULATION

\begin{tabular}{ccccc}
\hline Tablet & \multicolumn{2}{c}{ mg/tablet } & \multicolumn{2}{c}{$\begin{array}{c}\text { Assay (\% of label claim*) } \\
\text { Mean } \pm \text { S. D. }\end{array}$} \\
\cline { 2 - 5 } & CPD & LVX & \%CPD & \%LVX \\
GLEVO-POD & 200 & 250 & $99.85 \pm 0.4571$ & $100.03 \pm 1.2871$ \\
\hline
\end{tabular}

*Average of six estimations

The assay results were comparable to labeled value of each drug in tablet dosage form. These results indicate that the developed method is accurate, precise, simple and rapid. It can be used in the routine quality control of dosage form in industries. 


\section{CONCLUSION:}

$>$ The proposed method is simple, sensitive and reproducible and hence can be used in routine for determination of Cefpodoxime proxetil and Levofloxacin Hemihydrate in pharmaceutical preparations.

The values of percentage recovery and standard deviation show that the proposed methods were reproducible, accurate and precise.

$>$ The developed methods can be used for routine quantitative estimation of Cefpodoxime proxetil and Levofloxacin Hemihydrate in their combined pharmaceutical preparation.

ACKNOWLEDGEMENT: Authors are thankful to Sunrise Remedies, Ahemdabad for providing free gift sample and ROFEL Shri G.M Bilakhia college of Pharmacy, Vapi for providing necessary facilities and constant encouragement.

\section{REFERENCES:}

1. Dong W. Modern HPLC for Practicing Scientists; A Wiley- Inter science publication, USA, 2006, pp 1-9.

2. ICH, Validation of Analytical Procedures; Methodology, Q2 (R1), International Conference on Harmonization, IFPMA, Geneva 1996.
3. Siddalinga M, Shetty A and Kumar A, "UV-Visible Spectrophotometric method for the estimation of Cefpodoxime Proxetil in Bulk drug and Pharmaceutical dosage form.'International Journal of Pharm tech Research.2012, 4(02), 750-756.

4. Shah M, Patel H and Patel C, "Development and validation of spectrophotometric method for simultaneous determination of Cefpodoxime Proxetil and Ofloxacin in tablets."International Journal of Pharmaceutical Sciences and Research. 2012, 3(2), 551-555.

5. Shah D, Talaviya S and Patel M, "Simultaneous Estimation of Cefpodoxime Proxetil and Ofloxacin in Pharmaceutical Dosage Form by RPHPLC.'International Journal of Pharmacy and Pharmaceutical Sciences, 2012, 4(3), 627-630.

6. Thangabalan B, Sreedivya L, Madhuri N, Naseema S, Azeez S and Vijayar P, "Spectrophotometeric Determination of Levofloxacin Pure \& In Its Tablet Dosage Form" Asian Journal of Biochemical and Pharmaceutical Research.2012, 2(1)

7. Gerad S and Vipin P, "Method development and validation of Cefpodoxime Proxetil by UVSpectrophotometric method in bulk drug and formulation.'International Journal of Pharmaceutical Research and Development. 2012, 4(04), 276-280.

8. Acharya D, Patel D and Patel V, "Development and validation of first order derivative spectrophotometric method for simultaneous estimation Dicloxacillin and Cefpodoxime Proxetil in tablet dosage form." Journal of Drug delivery and Therapeutics. 2012, 2(1)1-5.

9. Japanese Pharmacopeia XVI, The Ministry of Health, Labour and Welfare, Japan,. 2011, 581-82, 1031-32.

\section{How to cite this article:}

Desai SM, Dalwadi H and Viradiya D: Development and validation of RP-HPLC method for simultaneous estimation of cefpodoxime proxetil and levofloxacin hemihydrate in combined dosage form. Int J Pharm Sci Res 2016; 7(9): 3742-48.doi: 10.13040/IJPSR.09758232.7(9).3742-48.

All $\odot 2013$ are reserved by International Journal of Pharmaceutical Sciences and Research. This Journal licensed under a Creative Commons Attribution-NonCommercial-ShareAlike 3.0 Unported License.

This article can be downloaded to ANDROID OS based mobile. Scan QR Code using Code/Bar Scanner from your mobile. (Scanners are available on Google Playstore) 